\title{
ANALISIS PERKEMBANGAN FINANCIAL TECHNOLOGY (FINTECH) SYARIAH PADA MASA PANDEMI COVID-19 DI INDONESIA
}

\author{
Ahmad Yudhira \\ Fakultas Ekonomi Universitas Tjut Nyak Dhien, Program Studi Akuntansi \\ Email: ahmadyudhiraMSC@gmail.com
}

\begin{abstract}
The development of Islamic Fintech during the Covid -19 pandemic provided its blessings. Sharia fintech can be used as a solution to strengthening the economy. Opportunities that can be achieved in developing sharia fintech in the future include the large number of Indonesian adults who have not been touched by financial services, changes in people's lifestyles towards digitalization, and support from the government through clear regulations and legal frameworks. On the other hand, several obstacles hinder the development of Islamic fintech, namely a large number of illegal fintech that thrives in Indonesia, inadequate infrastructure, low public awareness of Islamic finance, and the quality of human resources not optimal.
\end{abstract}

Keywords: Financial, Technology, Fintech Syariah

\begin{abstract}
Abstrak
Perkembangan Fintech syariah dimasa pandemic covid -19 memberikan berkah tersendiri. Fintech syariah dapat dijadikan salah satu solusi penguatan ekonomi. Peluang yang dapat diraih dalam mengembangkan fintech syariah kedepannya antara lain yaitu masih banyaknya penduduk dewasa Indonesia yang belum tersentuh layanan Financial, perubahan gaya hidup masyarakat ke arah digitalisasi, serta dukungan dari pemerintah melalui regulasi dan payung hukum yang jelas. Disisi lain terdapat beberapa kendala yang menghambat perkembangan fintech syariah yaitu banyaknya fintech-fintech illegal yang tumbuh subur di Indonesia, infrastruktur yang kurang memadai, kesadaran masyarakat tentang keuangan syariah masih rendah, serta kualitas SDM yang masih belum maksimal.
\end{abstract}

Kata Kunci: Financial, Tekhnologi, Fintech syariah

\section{Pendahuluan}

Presiden Joko widodo secara resmi mengumumkan masuknya covid 19 tertanggal 2 Maret 2020 ke Indonesia, Presiden mengumumkan terdapat dua orang warga Negara Indonesia yang pertama kali terpapar virus tersebut, kemudian lonjakan pasien terinfeksi semakin meningkat, sehingga dibuatkan keputusan untuk melaksanakan PSBB (pembatasan social skala besar) di Indonesia hal ini berdampak kepada ditutupnya sekolah-sekolah, sebagian kantor-kantor, pabrik dan banyak fasilitas umum lainnya yang mengakibatkan menurunnya prekonomian.

Untuk meminimalisasi dampak perekonomian maka banyak kantor-kantor baik swasta maupun pemerintah menerapkan 
WFH (work from home). Pemerintah juga menghimbau kepada masyarakat untuk mengurangi pekerjaan di luar rumah sebagai bagian untuk meminimalisasi penyebaran virus covid -19 .

Disisi lain perkembangan teknologi semakin pesat pada era digital sekarang ini, hal ini diikuti dengan perkembangan bidang keuangan khususnya Fintech. Fintech atau Financial tecnologi lebih merujuk kepada istilah yang menunjukkan pada badan usaha yang menawarkan teknologi maju pada bidang keuangan. Fintech-fintech tersebut berkembang sejak tahun 2010 yang kebanyakan merupakan perusahaan mikro, kecil atau menengah. Dengan modal yang kurang memadai tetapi mempunyai gagasan yang jelas tentang bagaimana mempromosikan peningkatan layanan dalam keuangan.

Konsep teknologi financial meliputi layanan keuangan berlandaskan sistem digital yang telah berkembang di Indonesia seperti digital banking, online digital insurance, payment channel system, to Peer (P2P) Lending,maupun crowd funding merupakan adaptasi dari perkembangan teknologi yang menyandingkan antara sector financial dengan kemajuan teknologi, sehingga kedepannya proses transaksi keuangan akan menjadi lebih canggih, mudah dan aman Siregar (2016)

Pada tahun 2006 hanya terdapat empat perusahaan Fintech kemudian pada tahun 2007 terus berkembang menjadi 16 perusahaan. Kemudian pada tahun 2015 terjadi kenaikan perkembangan Fintech, hal ini terus berlanjut hingga sekarang, yang mana jumlah fintech tahun 2020 ini sekitar 161 perusahaan terdaftar di otoritas jasa keuangan (OJK). Sedangkan menurut Satgas Waspada Investasi (SWI) Tongam L Tobing dalam wiratmini (2020) terdapat 508 entitas fintech peer to peer lending berstatus ilegal selama Januari - Maret 2020 sedangkan sebanyak 2.406 entitas telah terdata sejak tahun 2018 hingga Maret 2020 .

Seiring dengan perkembangan fintech, muncullah ide untuk menghalalkan Fintech agar umat muslim di Indonesia dapat menggunakannya sesuai dengan Syariat Islam, dengan adanya lebel syariah pada fintech tersebut, akan menjadi suatu peluang yang sangat besar dalam prospek kedepan bagi industri fintech syariah di Indonesia, ditambah lagi keberadaan FinTech ini akan semakin menguntungkan karena adanya perubahan perilaku masyarakat Indoneisa yang akhir-akhit ini gemar melakukan transaksi secara online/ 
digital. Apalagi disaat pandemic covid -19 ini yang memaksa masyarakat untuk lebih banyak melakukan aktivitas di dalam rumah.

Beehive merupakan fintech yang pertama kalinya mengumumkan penggunaan sistem syariah dengan pendekatan peer to peer $(P 2 P)$ lending marketplace pada tahun 2014. Beehive sendiri muncul di Dubai, Uni Emirat yang kini menjadi salah satu lembaga teknologi keuangan yang unggul diantara pesaingnya dengan skala pasar yang sangat luas. Dengan keunggulan ini menjadikan fintech syariah meluas ke neraga Asian lainnya.

Di Indonesia Fintech syariah memiliki payung hukum yaitu berlandaskan Peraturan Otoritas Jasa Keuangan (POJK) 77 Tahun 2016 tentang Layanan Pinjam Meminjam Uang Berbasis Teknologi Informasi. Aturan ini juga berlaku untuk fintech konvensional maupun Syariah. Tetapi ada peraturan tambahan untuk fintech syariah yaitu harus mengacu kepada Fatwa Dewan Syariah Nasional Majelis Ulama Indonesia (DSN MUI) Nomor 117/2018 tentang Layanan Pembiayaan Berbasis Teknologi Informasi Berdasarkan Prinsip Syariah.

Pada masa pandemic covid-19 ini kemungkinan untuk perkembangan fintech syariah di Indonesia dapat mengalami peningkatan. Maka dalam kesempatan ini penulis akan membahas tentang peluang dan ancaman perkembangan fintech syariah pada masa pandemic covid -19 di Indonesia.

\section{Tinjauan Pustaka}

\subsection{Pengertian Financial Technology} (Fintech)

Financial technology (Fintech) mengacu kepada defenisi National Digital Research Center (NDRC) yaitu sebagai inovasi keuangan pada lingkup jasa keuangan atau financial, Adapun Inovasi ini menggabungkan antara financial dan teknologi modern. Secara sederhana fintech merupakan penggabungan antara jasa keuangan dan teknologi terkini, fintech sendiri dapat diistilahkan sebagai usaha dalam memaksimalkan pemakaian teknologi mulai dari metode pembayaran, transfer, pinjaman, pengumpulan dan hingga pengelolaan asset, untuk memperkuat, mengubah dan mempercepat berbagai bidang pelayanan keuangan yang dapat dilakukan secara cepat dan ringkas Maulida (2019).

Defenisi Financial technologi (FinTech) menurut Bank Indonesia dalam Marginingsih (2019) yaitu hasil perpaduan antara tehnologi terkini dengan jasa keuangan yang mengubah model bisnis sederhana (misalnya melakukan 
pembayaran secara langsung, membayar dengan uang cash) menjadi berimbang (misalnya transaksi tidak secara langsung tetapi menggunakan media online dan juga melakukan pembayaran secara online).

Sedangkan defenisi Fintech syariah merupakan penggabungan antara teknologi dan keuangan yang menghasilkan kemudahan pada proses informasi dan transaksi pada bidang teknologi keuangan yang berdasarkan syariat atau hukum Islam.

\subsection{Jenis-Jenis Financial Technology (Fintech)}

Menurut Siregar (2016) Fintech (Financial Technology) dapat dibedakan ke dalam beberapa kategori:

1. Payment Channel/System, yaitu sistem pembayaran atau layanan elektronik menggunakan kartu danemoney atau dapat juga berupa sistem pembayaran berbasis kriptografi (blockchain) misalnya Bitcoin yang telah banyak di gunakan oleh masyarakat dunia. Sistem ini digunakan untuk menggantikan fungsi uang kartal maupun giral sebagai alat pembayaran.

2. Digital Banking, yaitu sistem yang digunakan oleh perbankkan untuk memberikan layanan dengan memanfaatkan teknologi digital/online dalam memenuhi kebutuhan nasabahnya. Contoh dari digital Banking dapat berupa SMS banking, internet banking, phone banking, mobile banking, video banking dan yang paling dikenal oleh masyarakat yaitu ATM, dan juga EDC. Selain itu, ada juga beberapa bank meluncurkan Layanan Keuangan Tanpa Kantor dalam rangka Keuangan Inklusif (Laku Pandai), layanan ini merupakan layanan keuangan tanpa kantor (branchless banking) yang sudah sesuai dengan kebijakan OJK. Adapun tujuan yang paling esensial adalah diarahkan kepada seluruh masyarakat yang belum memiliki akses ke perbankan.

3. Online/Digital Insurance, layanan ini digunakan oleh perusahaan-perusahaan asuransi dimana nasabah dapat memanfaatkan teknologi digital ini. Misalnya web portal yang digunakan oleh beberapa perusahaan asuransi untuk mempromosikan produk asuransinya, menerbitkan polis, dan juga menerima laporan klaim dari nasabah. Di samping itu, sebagian besar perusahaan-perusahaan asuransi menggunakan website atau mobile application untuk menawarkan jasa perbandingan premi (digital consultant) dan juga keagenan (digital marketer). 
4. Lending Peer to peer (P2P) yaitu sistem layanan keuangan yang memposisikan dirinya sebagai market untuk mempertemukan antara pihak peminjam dengan pihak pemberi pinjaman dengan cara memanfaatkan teknologi digital, dimana kebanyakan layanan ini menggunakan website.

5. Crowdfunding yaitu merupakan sistem untuk mengumpulkan modal menggunakan website atau teknologi digital lainnya dengan tujuan investasi maupun kegiatan sosial.

\subsection{Perbedaan Fintech syariah dan Konvensional}

Perbedaan antara Fintech konvensional dan syariah terletak pada Prinsip dasarnya. Fintech Konvensional menggunakan sistem bunga sedangkan Fintech syariah menggunakan syariat Islam. Dalam menjalankan kegiatan usahanya, fintech berbasis syariah maupun konvensioanal harus menaati peraturan yang dikeluarkan oleh OJK Nomor 77/POJK.01/2016 tanggal 26 Desember 2016 tentang Layanan Pinjam Meminjam Uang Berbasis Teknologi Informasi, namun khusus Fintech Syariah terdapat tambahan selain mengacu kepada peraturan yang sudah diterbitkan oleh OJK, juga mengacu kepada Fatwa Dewan Syariah Nasional-
Majelis Ulama Indonesia (DSN-MUI) No: 117/DSN-MUI/II/2018 tentang Layanan Pembiayaan Berbasis Teknologi Informasi Berdasarkan Prinsip Syariah.

\subsection{Jenis-jenis Akad dalam Fintech Syariah}

Ketua Umum Asosiasi Fintech Syariah Indonesia (AFSI) Ronald Yusuf Wijaya dalam Evandio (2020) mengatakan Transaksi antara pemberi pinjaman, dan peminjam bersifat kerja sama artinya fintech syariah tidak mengenakan bunga melainkan sistem bagi hasil dengan tenor yang telah disepakati sebelumnya.

Menurut Ronald terdapat enam jenis akad yang diperbolehkan dalam fintech syariah, yaitu:

1. Al-bai' (jual-beli), yaitu akad jual beli dimana terjadi pertukaran baik barang maupun jasa antara pedagang dan konsumen yang mengakibatkan beralihnya hak milik.

2. Ijarah merupakan suatu akad yang dilakukan dengan memberi ujrah atau upah atas barang atau jasa yang telah dipindahkan hak guna/manfaatnya.

3. mudharabah merupakan suatu akad kerjasama yang dilakukan oleh pemilik modal dengan pengelola modal dengan syarat bahwa keuntungan dari usaha tersebut akan dibagi sesuai dengan 
nisbah yang telah disepakati.

Sementara itu jika terjadi kerugian maka akan ditanggung oleh pemilik modal.

4. Musyarakah, merupakan suatu akad persekutuan antara dua atau lebih kelompok dalam membuat/membuka suatu kegiatan bisnis tertentu, di mana semua pihak memberikan andil berupa modal usaha. Pada konsep akad Musyarakah ini terdapat ketetapan yaitu jika perusahaan/usaha yang dijalani mengalami keuntungan maka hasil keuntungan akan dibagi sesuai poporsi yang telah disepakati, sedangkan jika terjadi kerugian maka ditanggung oleh semua pihak secara proporsional.

5. Wakalah bi al ujrah merupakan akad untuk pemberian kuasa kepada seseorang ataupun usaha dalam melakukan aktivitas hukum tertentu yang disertai dengan imbalan berupa ujrah (upah).

6. Qardh merupakan suatu akad pinjam meminjam (pinjaman yang diberikan oleh donatur) dengan ketentuan bahwa penerima pinjaman wajib mengembalikan uang yang diterimanya sesuai dengan waktu dan cara yang telah disepakati sebelumnya.

\section{Metode Penelitian}

Pada penulisan penelitian ini metode yang digunakan adalah teknik analisis deskriptif kualitatif, dimana seluruh datadata yang dihasilkan dan disajikan berbentuk deskripsi yaitu berupa gambaran tentang hasil dari penelitian. Teknik pengumpulan data yang digunakan antara lain pendekatan studi literature online maupun cetak, dan kepustakaan yang berkaitan dengan penelitian ini.

\section{Hasil Penelitian dan Pembahasan}

\subsection{Hasil Penelitian}

Berbicara tentang Evolusi fintech di awali pada tahun 1866-1987 yaitu munculnya pesanan produk dari konsumen yang dilakukan menggunakan telpon. Para Pedagang dapat dengan mudah memesan produk/barang yang mereka butuhkan dimanapun mereka berada hanya melalui telepon, maka terjadilah peredaran kekayaan di seluruh dunia tanpa tenaga atau bahkan masalah. Kemudian perkembangan terus terjadi dari tahun 1987-2008 menjadi "The Automatic Teller Machine (ATM) dan yang terakhir tahun 2008 sampai saat ini yaitu ratusan Startups menawarkan berbagai alternatif untuk perbankan yang masih mengadopsi sistem tradisional.

Platform fintech secara umum mulai berkembang pesat dari tahun 2015 hingga 
Vol. 1 No. 2 Bulan Oktober - Maret 2021

sekarang yang sebagian besar masih berasaskan sistem konvensional. Humayon Dar selaku Direktur Jenderal Islamic Research \& Training Institute (IRTI) memberikan pernyataan bahwa "nilai industri syariah secara global masih sangat kecil jika dibandingkan dengan industri konvensional", namun dalam perkembangannya mulai berdiri beberapa fintech syariah pada tahun 2018. Pertambahan ini nantinya diharapkan akan menjadi gebrakan bagi industry fintech syariah dalam perkembangannya dimasa akan datang. Industri fintech di Indonesia menurut Otoritas Jasa Keuangan (OJK) terbagi kepada beberapa sector yaitu : 1) financial planning, 2) crowdfunding, 3) lending, 4) aggregator, 5) payment, dan 6) fintech lainnya.

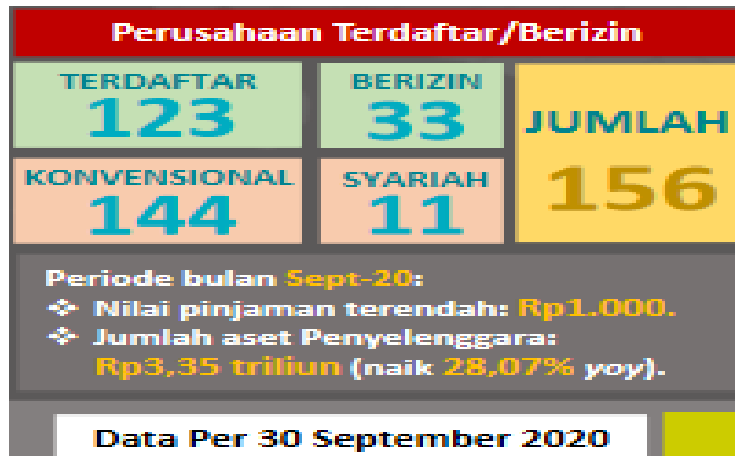

Sumber: https://www.ojk.go.id/id/kanal/iknb/datadan-statistik/fintech/Pages/-Statistik-FintechLending-Periode-September-2020.aspx

Gambar. 1. Data Perusahaan Fintech yang berizin dan terdaftar Berdasarkan data per 30 September

2020 di atas, terdapat sebanyak 156 perusahaan yang mendaftarkan diri ke Otoritas Jasa Keuangan (OJK). 144 perusahaan merupakan Fintech berlandaskan konvensional dan sisanya yaitu 11 perusahaan merupakan fintech syariah. Dari jumlah tersebut di atas hanya ada sekitar 33 perusahaan saja yang memliki status berizin, sedangkan sisanya 123 perusahan memiliki status terdaftar. Untuk tahun-tahun kedepannya kemungkinan, keberadaan Industri fintech syariah akan semakin meningkat.

Dari 11 perusahaan Fintech syariah per 30 september 2020 terdapat 2 (dua) fintech syariah yang telah memiliki izin dari OJK dan sisanya 9 (sembilan) fintech syariah yang telah berstatus terdaftar. maka data total ke 11 (sebelas) fintech syariah adalah sebagai berikut:

\section{Ammana (Status berizin)}

Ammana merupakan salah satu perusahaan Fintech yang mengklaim dirinya sebagai fintech syariah pertama di Indonesia yang terdaftar di OJK. Ammana mulai beroperasi sejak bulan Maret tahun 2018, Dengan fokus aktivitas pendanaan kepada para pelaku Usaha Mikro, Kecil dan Menengah (UMKM). Ammana memberikan pendanaan mulai dari $\mathrm{Rp} 500.000$,- (lima ratus ribu rupiah) hingga $\mathrm{Rp} 2.000 .000 .000,-$ 
(dua milyar rupiah) serta pelaku UMKM dapat menyesuaikan akad perjanjiannya dengan kebutuhan masing-masing. Pada tanggal 13 Desember 2019 mendapatkan surat tanda berizin No. KEP -123/D.05/2019 dengan sistem Android dan IOS.

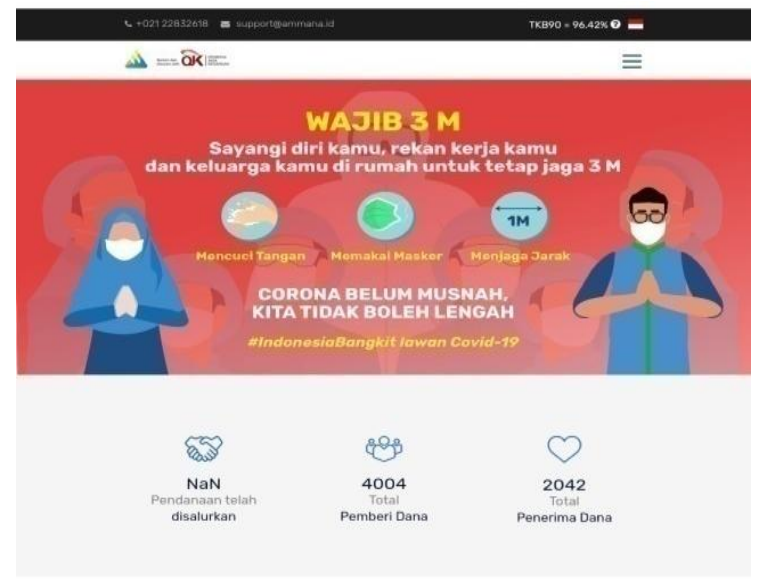

Sumber: https://Ammana.id

Gambar. 2 Tampilan depan Ammana.id

\section{Alami Sharia (Status Berizin)}

Alami Sharia merupakan fintech pembiayaan yang menyasar para pelaku UMKM dengan memberikan piutang (Invoice Factoring) mulai dari dari Rp 200.000.000,- (dua ratus juta rupiah) hingga Rp 2.000.000.000,- (dua milyar rupiah) . Alami syaria menjalankan usahanya sejak februari 2018 dengan konsep aggregator dan peer to peer $(\mathrm{P} 2 \mathrm{P})$ lending. Beberapa kerjasama yang telah dijalin diantaranya dengan Bank syariah seperti BNI Syariah, Bank Mega Syariah, dan Jamkrindo Syariah dan Alami syariah juga bermitra dengan Kapital Boost (fintech lending singapura). Alami Sharia mendapat surat Tanda Berizin dari OJK mulai tanggal 27 Mei 2020 dengan nomor surat KEP21/D.05/2020 dengan sistem Android dan IOS.

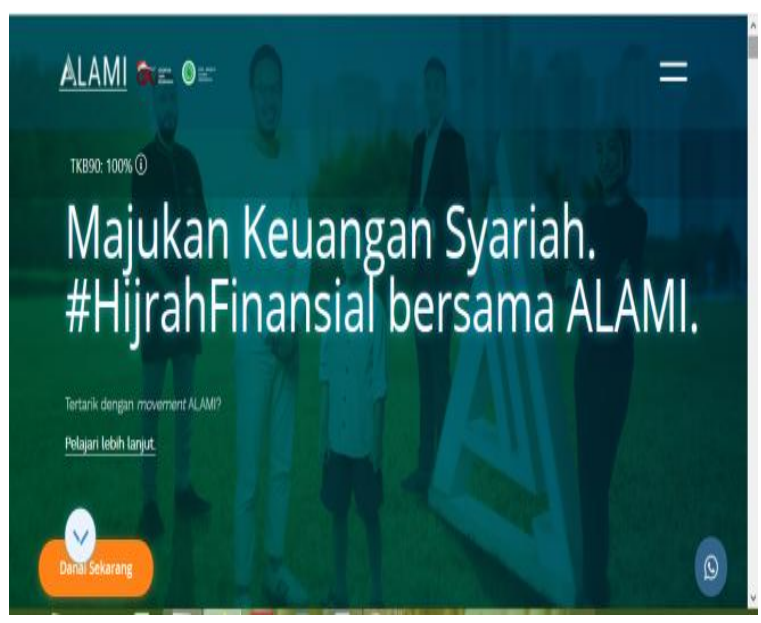

Sumber: https://p2p.alamisharia.co.id

Gambar. 3 Tampilan depan Alamisyariah.id

\section{Dana Syariah (Status Terdaftar)}

Dana syariah adalah salah satu fintech syariah yang resmi terdaftar di OJK tertanggal 08 Juni 2018 dengan Nomor surat tanda terdaftar S-384/NB.213/2018 menggunakan sistem android yang berfokus pada bidang property mulai dari pembelian lahannya, pembangunan rumah serta pembangunan fasilitas penunjang lainnya. Dana Syariah juga menyediakan layanan untuk penghitungan zakat dan penyaluran ke pihak yang tepat. Nilai pembiayaan mulai dari Rp1.000.000.000,- (satu milyar rupiah) dengan waktu angsuran mulai dari satu tahun. 


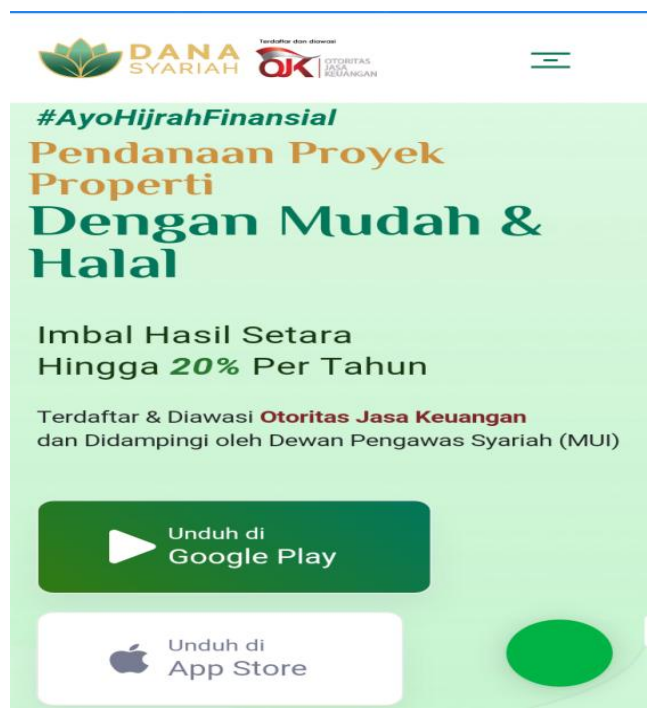

Sumber: https://Danasyariah.id

Gambar. 4 Tampilan depan Danasyariah.id

\section{Danakoo Syariah (Status terdaftar)}

Danakoo Syariah memberikan layanan Syariah Peer-to-Peer Lending Platform khusus pinjaman untuk karyawan (Employee Loan) dan Anggota Komunitas dengan misi mewujudkan kemerataan dan keadilan ekonomi melalui inovasi finansial teknologi berbasis Syariah. Danakoo syariah berperan sebagai marketplace yang mempertemukan antara peminjam dengan pemberi pinjaman. Nilai pembiayaannya di mulai dari Rp500.000,- hingga Rp50.000.000 untuk setiap pemohon. Dengan menggunakan sistem android Danakoo Syariah resmi terdaftar di OJK dengan nomor S-67/NB.213/2019 tertanggal 01 Februari 2019

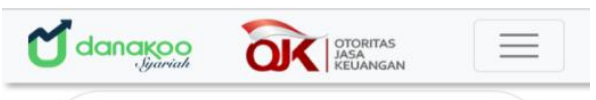

\section{Pembiayaan}

Membantu menyediakan peluang pendanaan atas kebutuhan pembiayaan Anda dengan proses yang cepat dan mudah dengan imbal hasil yang terjangkau.

\section{Ajukan Pembiayaan}

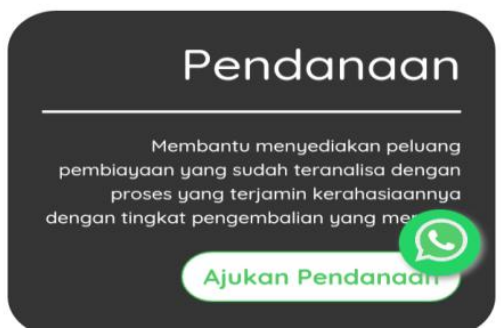

Sumber: www.danakoo.id

Gambar. 5 Tampilan depan Danakoo.id

\section{Qazwa (Status Terdaftar)}

Qazwa merupakan salah satu fintech syariah yang berfokus pada pembiayaan dalam pengembangan bisnis atau usaha dengan lingkup pembiayaan untuk jenis industri perdagangan, peternakan, perkebunan, pengolahan, dan lain sebagainya. Qazwa Jangka waktu pelunasan mulai dari enam bulan hingga satu tahun.

Qazwa didirikan pada Maret 2018 bertindak sebagai marketplace yang mempertemukan antara investor dan peminjam selaku pihak UMKM untuk proses penanaman Modal usaha. Qazwa resmi terdaftar di OJK tertanggal 07 Agustus 2019 dengan Nomor surat tanda terdaftar S440/NB.213/2019 . 
Vol. 1 No. 2 Bulan Oktober - Maret 2021

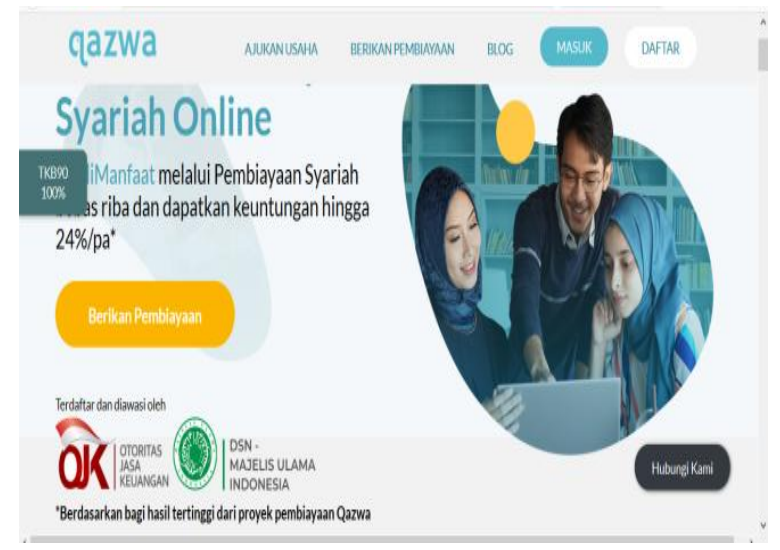

Sumber: https://qazwa.id/

Gambar. 6 Tampilan depan Qazwa

\section{Duha Syariah (Status Terdaftar)}

Duha Syariah terdaftar di Otoritas Jasa keuangan (OJK) dengan Nomor S292/NB.213/2019 tertanggal 30 April 2019

Dua jenis layanan yang disediakan Duha Syariah yaitu:

a. Pembiayaan konsumtif (barang/jasa) (Produk Halal) dengan Pembiayaan mulai dari Rp1.500.000,- hingga Rp 20.000.000,- dan dengan pilihan masa angsuran mulai dari 3 bulan hingga 12 bulan.

b. Pembiayaan perjalanan religi. Yaitu umroh dan wisata halal yang dijual di $e$ commerce atau marketplace mitra Duha Syariah, dengan limit maksimal $\mathrm{Rp}$ 30.000.000,- (tiga puluh juta rupiah) dan terdapat pilihan masa angsuran mulai dari 12 bulan, hingga 24 bulan.
App Duha Syariah! Pembiayaan Syariah, , Bebas Ribet! $\checkmark$ google Play TKB9O $=99.27 \%$ C
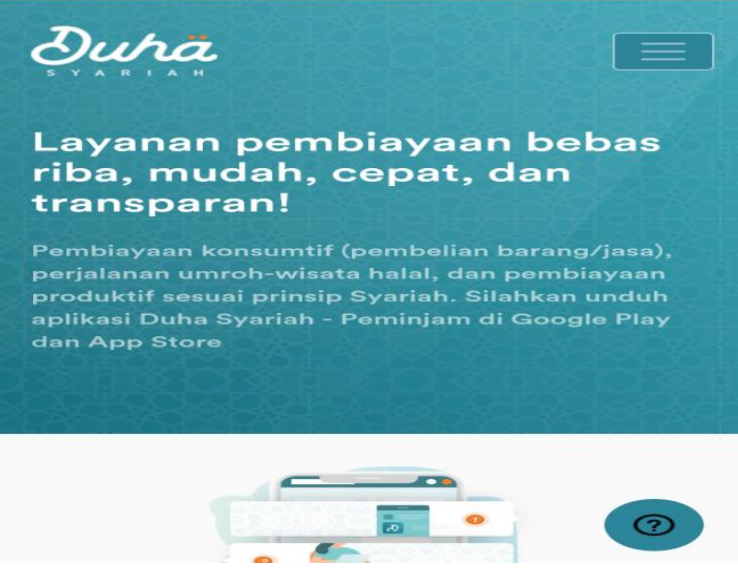

(?)

Sumber: https://duhasyariah.id/

\section{Gambar. 7 Tampilan depan Duha Syariah}

7. Bsalam (Status Terdaftar)

Bsalam resmi terdaftar di Otoritas Jasa Keuangan (OJK) dengan nomor surat tanda terdaftar S-441/NB.213/2019 tertanggal 7 agustus 2019 yang bertumpu pada pembiayaan modal kerja Penyelenggara Perjalanan Ibadah Umroh (PPIU) dan juga Penyelenggara Ibadah Haji Khusus (PIHK). Bsalam mengenakan biaya layanan bagi setiap peminjam dengan besaran 2,5\% per pinjaman. Sedangkan bagi investor mendapatkan bagi hasil sekitar $16 \%$ hingga $18 \%$.
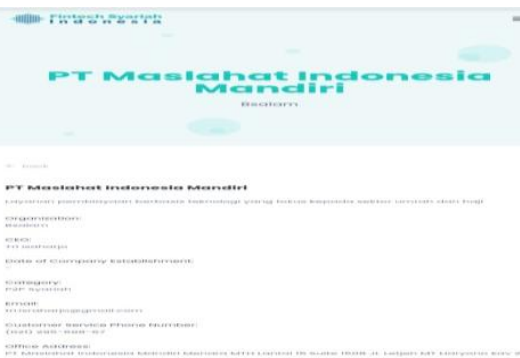

Sumber: Www.bsalam.id

Gambar. 8 Tampilan depan Bsalam 


\section{Ethis (Status Terdaftar)}

Ethis merupakan Layanan flatform

fintech syariah berdasarkan peer-to-peer (P2P) lending yang berfokus pada segmen pembangunan rumah subsidi dan rumah sederhana (proyek property) di Indonesia. Beroperasi sejak tahun2014 dan resmi terdaftar di OJK tanggal 30 oktober 2019 dengan nomor tanda bukti terdaftar $\mathrm{S}$ 608/NB.213/2019.

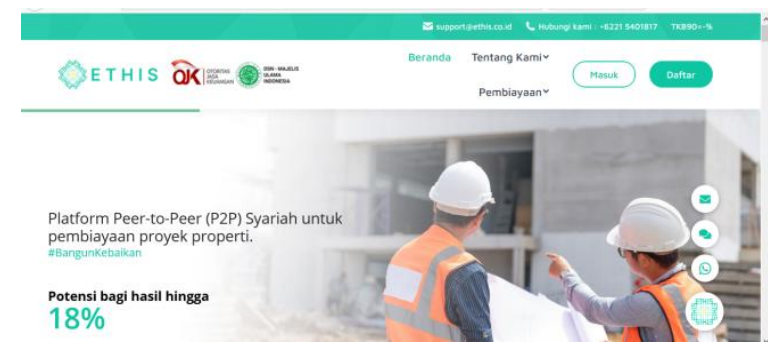

Sumber: https://www.ethis.co.id/

Gambar. 9 Tampilan depan Ethis

\section{Kapital Boost (status terdaftar)}

Kapital Boost didirikan pada 12 Juni 2015 di Singapura dengan tujuan membantu UKM di Asia Tenggara dan terdaftar di OJK pada tanggal 30 oktober 2019 dengan nomor bukti terdaftar S-609/NB.213/2019.

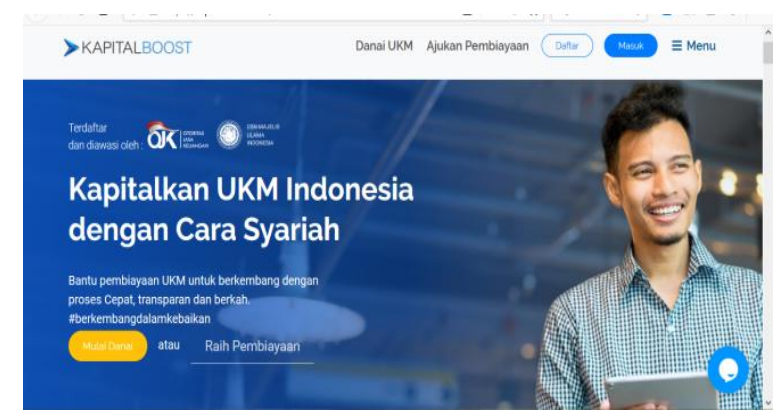

Sumber: https://kapitalboost.co.id/

Gambar. 10 Tampilan depan Kapital Boost

\section{Papitupi Syariah (Status Terdaftar)}

Papitupi Syariah mulai beroperasi pada bulan Desember 2019 yang memiliki tujuan untuk memberikan penyelesaian bagi ketercakupan keuangan di Indonesia, Papitupi memberikan pembiayaan untuk karyawan yang memiliki kualifikasi terbaik sekaligus ikut serta membangun ekonomi Syariah di Indonesia yang akan membawa kebaikan dan kesejahteraan bagi seluruh rakyat Indonesia.

Papitupi Syariah resmi terdaftar di OJK pada tanggal 30 oktober 2019 dengan nomor bukti terdaftar S-612/NB.213/2019. Papitupi Syariah memberikan layanan berupa pembiayaan yang difungsikan untuk mencukupi kebutuhan sehari-hari baik berupa barang atau jasa, Papitupi Syariah memberikan batas maksimal pinjaman sebesar Rp. 10.000.000,- dengan biaya penanganann $\mathrm{Rp} 50.000,-$ hingga $\mathrm{Rp}$ 300.000,- sebanding dengan total pinjaman yang diajukan.

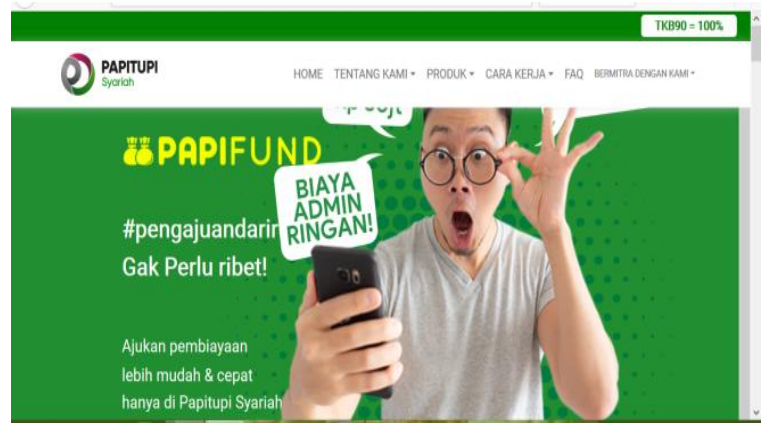

Sumber: https://www.papitupisyariah.com/ Gambar. 11 Tampilan depan Pipitupi Syariah

\section{Fintech Syariah}


Fintech Syariah resmi terdaftar di Otoritas Jasa Keuangan (OJK) tanggal 30 oktober 2019 dengan nomor tanda terdaftar S-600/NB.213/2019. Fokus Fintech Syariah yaitu pembiayaan pada industri kecil menengah (IKM) dan usaha kecil menengah (UKM) dikhususkan pada bidang perikanan, peternakan dan properti syariah

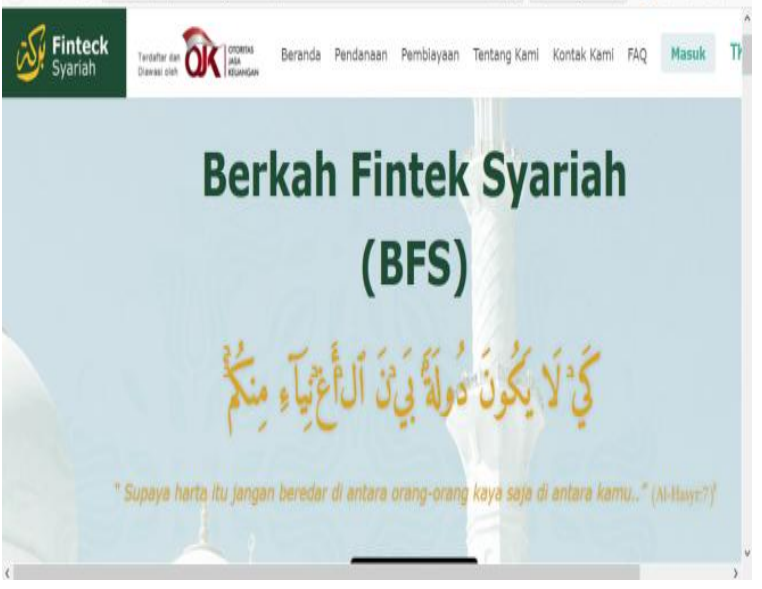

Sumber: https://www.finteksyariah.co.id/

Gambar. 12. Tampilan depan Fintech Syariah

Indonesia merupakan negara dengan penduduk muslim terbanyak, yang pertumbuhannya cukup siginifikan tetapi dalam pembiayaan syariah masih jauh tertinggal jika dibandingkan dengan Negaranegara tetangganya. Berdasarkan data yang dihimpun oleh Google, Tamasek Brain dan Company pada bulan oktober tahun 2019 menyatakan bahwa lebih dari setengah jumlah penduduk dewasa Indonesia belum tersentuh Layanan Finansial.

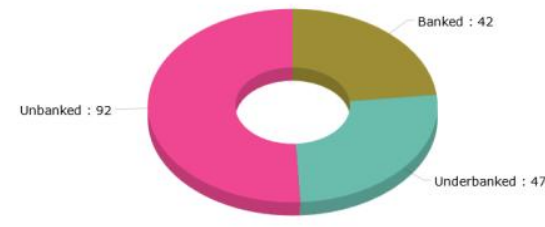

Satuan : Juta Jiwa

Dkatadata

Sumber: Google, Temasek,Bain \& company, okt 2019 dalam kusnandar (2019)

Gambar 13. Jumlah penduduk dewasa Indonesia yang sudah dan belum tersentuh layanan finansial

Dikutip juga dari laporan annual member survey 2019/2020 oleh asosiasi Fintech Indonesia yaitu hanya $49 \%$ orang dewasa Indonesia yang memiliki akses ke rekening bank, sedangkan $51 \%$ sisanya belum memiliki akses. Di antara populasi yang belum memiliki rekening bank, 69\% memiliki ponsel sehingga mereka berpotensi menggunakan Financial technologi. Financial technologi dapat mempercepat inklusi keuangan karena Financial technologi membuka akses yang lebih besar ke layanan keuangan.

Hal ini juga didukung dengan perkembangan tingkat pengguna ponsel dan penetrasi internet yang telah meningkat dengan pesat. Saat ini, terdapat lebih dari 400 juta pengguna ponsel aktif, dan 45\% dari semua ponsel yang aktif adalah jenis smartphone (Indonesian Digital Report 2020) 
Pada tahun 2019, terdapat 175,4 juta pengguna internet dan diantara nya sebesar 160 juta pengguna merupakan pengguna media sosial aktif, dan $80 \%$ dari mereka mengakses internet melalui ponsel. Peningkatan jumlah pengguna smartphone berkontribusi signifikan terhadap adopsi Financial Technology (CCAF, ADBI, FinTechSpace (2019).

Penggunaan internet tumbuh secara eksponensial, yaitu sebesar $40 \%$ akibat pandemi COVID-19,. Berikut ini adalah grafik pertumbuhannya:

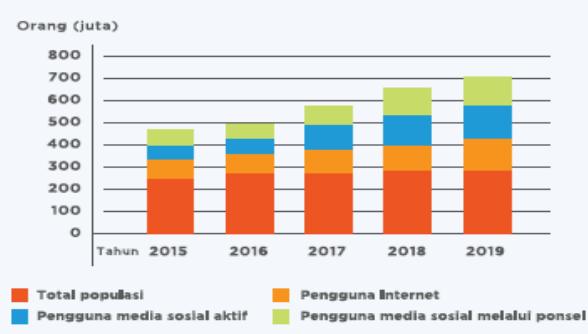

Sumber: Hootsuite: Laporan Digital Indonesia 2016-2020

Gambar 14. Pertumbuhan pesat pada penetrasi internet serta pengguna ponsel dan media social 2015 -2019

Adapun yang dapat dijadikan target pasar pada financial technology ini banyak menyasar pada Individu (perorangan) dan sector UMKM disinilah fintech syariah diharapkan banyak berperan. Berdasarkan penelitian yang dilakukan oleh Cambridge Centre for Alternative Finance (2019) menyatakan bahwa jumlah pelanggan financial technology yang terbanyak adalah individu dan disusul oleh sektor UMKM. Berikut ini adalah grafik nya:

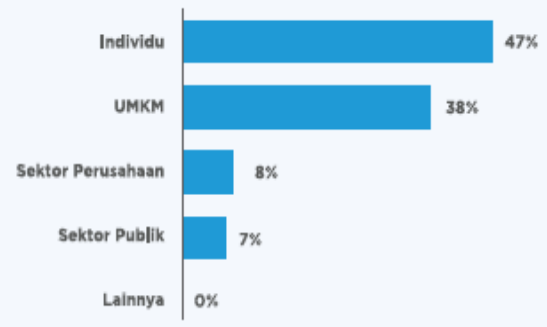

Sumber: Cambridge Centre for Alternative Finance (CCAF), 2019

Gambar 15. Jenis pelanggan Financial technology di Indonesia tahun 2019

Dalam perkembangannya banyak sekali bermunculan Fintech illegal yang dihimpun berdasarkan data dari Otoritas Jasa Keuangan (OJK) diketahui bahwa Satgas Waspada Investasi menemukan 126 fintech peer-to-peer lending (pinjaman online) ilegal pada September 2020. Dengan tambahan data tersebut, total jumlah fintech ilegal yang telah ditangani dan ditutup sejak 2018 sampai September 2020 menjadi 2.840 entitas perusahaan Idhom (2020).

Menurut Rektor Institut Tazkia, Murniati Mukhlisin, mengatakan berdasarkan hasil kajian yang dilakukan melalui Pusat FinTech Syariah Tazkia terdapat tiga kendala utama dalam perkembangan Fintech syariah yaitu pesatnya pertumbuhan Fintech illegal, 
Vol. 1 No. 2 Bulan Oktober - Maret 2021

Fintech konvesional yang terdaftar lebih mudah dan bervariasi, kurangnya modal dalam fintech syariah. Puspaningtyas (2020)

\subsection{Pembahasan}

Berdasarkan penjabaran dari hasil penelitian, yang dapat menjadi peluang dalam perkembangan Fintech syariah di Indonesia adalah

1. Besarnya jumlah penduduk Indonesia yang beragama Islam.

2. Banyaknya masyarakat Indonesia usia dewasa yang belum tersentuh layana financial

3. Peningkatan jumlah pengguna smartphone

4. Jumlah Individu maupun pengusaha baik UMKM ataupun perusahaan yang membutuhkan pinjaman yang dapat dijadikan target sasaran.

5. Dengan Sistem bagi hasil menjadi daya tarik tersendiri oleh masyarakat dimana Fintech mampu melayani masyarakat yang belum terlayani oleh industry keuangan (perbankkan) hingga ke pelosok desa/kampung.

6. Perubahan gaya hidup mayarakat.

7. Adanya regulator dan payung hukum sebagai bentuk dukungan dari pemerintah dalam perkembangan fintech syariah di tanah air.
8. Pandemic covid 19 yang di pandang dari sisi lain yaitu mampu mempercepat proses perkembangan Fintech di tanah air dan membantu pemulihan sector ekonomi yang secara tidak sengaja dipandang lebih aman karena kurangnya kontak langsung sehingga meminimalisasi penyebaran virus covid $-19$.

Adapun yang masih menjadi tantangan bagi perkembangan fintech syariah di tanah air adalah

1. Masih sedikitnya fintech syariah yang mendaftar ke OJK yang kemungkinan disebabkan oleh kurangnya modal dan pengetahuan tentang aturan bisnis dalam syariah.

2. Menjamurnya fintech-fintech illegal, serta persaingan dengan fintech konvensional yang notabene berkembang pesat.

3. Infrastuktur, minimnya kesadaran dan pengetahuan masyarakat tentang keuangan syariah, serta belum maksimalnya SDM yang berkualitas yang menunjang perkembangan Fitech syariah tersebut. 


\section{Kesimpulan dan Saran}

\subsection{Kesimpulan:}

Perkembangan fintech syariah di Indonesia masih memberikan peluang yang cukup besar dan terbuka lebar hanya saja harus diikuti dengan regulasi yang lebih mudah, infrastruktur yang memadai, serta sosialisasi tentang pemahaman keuangan syariah yang baik agar fintech syariah dapat lebih berkembang serta meminimalisasi tumbuh pesatnya fintech-fintech illegal.

Pandemic covid -19 memberi berkah tersendiri untuk perkembangan fintech di Indonesia khususnya fintech syariah ketika masyarakat dibayang-bayangi dengan ketidakpastian ekonomi fitech syariah membawa solusi untuk inovasi keuangan digital dimana transaksi lebih mudah, juga masyarakat dapat berkonsultasi tanpa bertemu secara fisik.

\subsection{Saran}

1. Perlu adanya perlakuan khusus dari pemerintah dalam menyikapi perkembangan fintech terutama fintech syariah, agar fintech-fintech illegal tidak tumbuh subur hingga akhirnya dapat merugikan masyarakat.

2. Penguatan sosialisasi yang menanamkan kepada masyarakat tentang keuangan syariah, sosialisasi dapat dilakukan melalui pemuka- pemuka agama yang disegani oleh masyarakat.

\section{DAFTAR PUSTAKA}

CCAF, ADBI, FinTechSpace.2019. ASEAN FinTech Ecosystem Benchmarking Study. Cambridge, UK.

Evandio, Akbar. 2020. Kenali Enam Jenis Akad di Fintech Syariah. https://finansial.bisnis.com/read/20 200226/231/1205982/kenali-enamjenis-akad-di-fintech. diakses tgl 19/10/2020-syariah. Pukul: 14:58 WIB

Idhom, Addi M. 2020. Data Fintech Ilegal Terbaru Temuan Satgas-OJK. https://irto.id/data-fintech-ilegalterbaru-temuan-satgas-ojk-update25-sept-2020-f5ct. diakses tgl 26 November 2020. Pukul 23:41 WIB

Indonesian Digital Report 2020. 2020. Digital 2020 Indonesia. Hootsuite (We are Social)

Kusnandar, Viva Budy. 2019. 92 Juta Penduduk Dewasa Indonesia Belum Tersentuh Layanan Finansial. https://databoks.katadata. co.id/datapublish/2019/10/08/92juta-penduduk-dewasa-indonesiabelum-tersentuh-layanan-finansial

Marginingsih, Ratnawaty. 2019. Analisis SWOT Technology Financial (FinTech) Terhadap Industri Perbankan. Journal Cakrawala Volume 19 No.1 Maret 2019 PISSN 1411-8629, E-ISSN: 25793314. 
Maulida, Ani. 2019. Fintech: Pengertian, Jenis, Hingga Regulasinya di Indonesia 2019.https://www.onlinepajak.com/tentang-pajak-pribadi /fintech. diakses tgl 19 oktober 2020 Pukul 13.30 WIB

Puspaningtyas, Lida. 2020. Kendala Utama Pengembangan Fintech Syariah. https://republika.co.id/ berita/q4c j9p368/kendala-utama-pengemba ngan-emfintech-em syariah. diakses tgl 26 nov 2020 pukul 23:49 WIB

Siregar, A. E. 2016. Financial Technology Tren Bisnis Keuangan Ke Depan. Retrieved December 27, 2018, from http://infobanknews.com

Wiratmini, Ni Putu Eka. 2020. Jumlah Fintech Ilegal Bertambah. https://ekonomi.bisnis.com/read/20 200314/9/1213283/jumlah-fintechilegal-bertambah. Diakses tgl 2/10/2020 pukul 10:19 WIB. 